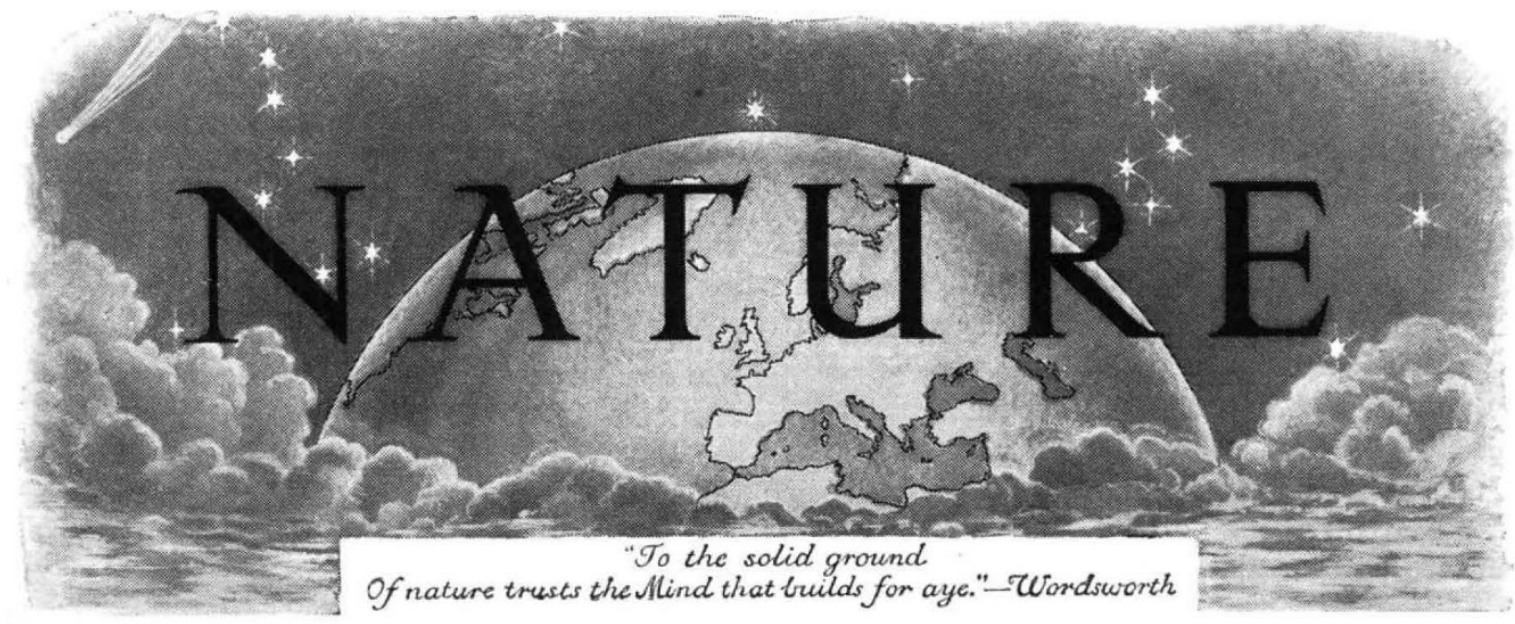

Vol. 141

SATURDAY, JANUARY 1, 1938

No. 3557

\title{
Jubilee Meeting of the Indian Science Congress
}

$\mathrm{T}^{\mathrm{H}}$ HIS week, the twenty-fifth meeting of the Indian Science Congress Association opens in Calcutta, the jubilee being marked by the attendance of a strong delegation from the British Association; Lord Rutherford was to have presided at the meeting, but fate decided otherwise, and the Association has been fortunate enough to persuade Sir James Jeans to take his place. It may be hoped that this meeting will confirm the growing appreciation in India of the value of modern science.

In the address prepared for the meeting by Lord Rutherford before his death, he pointed out that prior to the first decade of this century, scientific research in India was, with a few notable exceptions, confined to the great scientific services, initiated and maintained on a generous scale by the Government, such as the Survey of India, the Geological Survey, the Botanical Survey, the Departments of Agriculture and Meteorology, and others. To the work of members of the Trigonometrical Survey we owe the principle of isostasy, while the development of the mineral resources of the country has been due largely to the activities of the Geological Survey. In forestry, the fine research institute at Dehra Dun is a monument to the enthusiasm of past members of the Indian Forest Service. The Indian Medical Service has been the means of giving the world, not India alone, new weapons for the attack on tropical diseases such as malaria, cholera and leprosy.
While this work was going on steadily, the Indian universities were being founded, and at first attention was mainly directed to the instruction and examination of students. There were always a few, however, who realized the role the universities must eventually take in the promotion of research, and, as a result of the Curzon Commission on Education in 1904, many of the universities introduced honours courses, and by new appointments and improvements in laboratories stimulated research in science. Amongst the pioneer men of science in India who distinguished themselves by original investigations, Lord Rutherford mentioned in his address Sir Alexander Pedler, Sir J. Chandra Bose, Sir Alfred Bourne and Sir Prafulla Rây.

For geographical reasons, personal contact between scientific workers in India is difficult. Occasional meetings of specialists may be arranged by the Board of Scientific Advice, but these meetings do not affect the university teachers, and in the autumn of 1911 two newly appointed professors, P. S. MacMahon in Lucknow and J. L. Simonsen in Madras, feeling the isolation in which they worked, considered that the time was ripe for the organization in India of a body having the same aims and functions as the British Association for the Advancement of Science. After considerable discussion, and acting on the advice of Sir Thomas Holland, a small committee was constituted to consider the formation of such a body. This committee met on November 2, 1912, and it was decided to ask the Asiatic Society of Bengal 
(now the Royal Asiatic Society of Bengal) to arrange for the holding of a Science Congress in Calcutta in January 1913. Various difficulties, however, necessitated the postponement of this meeting until January 1914. The arrangements for the meeting were in the hands of the Royal Asiatic Society of Bengal, and thus commenced an association to which the Congress undoubtedly owes much of its success. The organization of the Congress has followed closely that of the British Association although, in view of their special importance in India, sections of medicine and veterinary science were included.

The numbers attending the first meeting, when the late Sir Asutosh Mukherjee, vice-chancellor of the University of Calcutta, was president, were small; some thirty scientific communications were read, mainly by authors resident in Calcutta or its vicinity. This appeared to justify the critics of the scheme who had suggested that geographical difficulties would preclude its success. However, the Government of India early recognized the potential value of the Congress and authorized the payment of expenses to selected Government servants. As a resuli, the second meeting, in Madras in 1915, was more largely attended and communications were received from authors as far distant as the Punjab and Ceylon. Since these early days, the Congress has grown very greatly, as shown by the size of the Proceedings, which in 1914 filled six pages and in 1928 four hundred and twenty.

Whilst this increase in the number of communications read to the various sections provides evidence of the growth of scientific inquiry in India, the main success of the Congress has been, as the original promoters had hoped, in the social contacts which it has provided and the public interest in science which it has aroused in the various centres it has visited. It has stimulated also the formation of such specialist societies as the Indian Botanical Society and the Indian Chemical Society.

While substantial progress in both teaching and research has been made by the universities of India, their responsibilities-and with them those of the Indian Science Congress Association-must inevitably increase. In this present scientific age, efforts are everywhere being made to develop natural resources to the utmost, to improve industrial processes and to increase our knowledge in pure science. It is to the universities and technical institutions that we must look for men to carry out this work. The universities must be able, not only to give instruction, but also to select those who are to be trained in the methods of research. From the latter we may expect to obtain future leaders of research, on whom the prosperity of the country will largely depend.

The utilization of science implies, moreover, a planned scheme of research. Here the experience of some of the Overseas Dominions may prove of service to India. In Canada and in Australia, there are State or Provincial Governments as well as a Federal Government, and in both cases it has been found expedient that the research organization of the country should be truly national and responsible to the Federal Government alone. Even in an Empire the size of India, where the resources and needs of various provinces are widely different, it would seem that centralized organization of research is the only way of avoiding waste of money and effort. The detailed planning of research must be in the hands of those with the necessary specialized knowledge, and they must be able to act without suspicion of political or racial influence. Here the Indian Science Congress Association has shown, over a long period of political turbulence, what can be accomplished, for a marked feature of the Congress has been the complete absence of racial and communal strife ; it has remained quite unaffected by these tragic influences, doubtless due in part to the tact of the various general officers and to the very valuable services of the secretary of the Royal Asiatic Society of Bengal, Mr. J. van Manen.

Since the foundation of the Indian Science Congress Association, it had always been hoped that it might prove possible to arrange for an over-seas visit of the British Association to India. The necessity, for climatic reasons, of holding such a meeting during the cold weather (November to February), the middle of the academic year, offered serious difficulties. However, they have now been overcome, and, moreover, the precedent has been established of sending a delegation to a joint meeting with another organization. This is undoubtedly of great significance. Valuable as are personal contacts within a country, such contacts with workers in other countries and the opportunity of seeing the conditions under which they work are of even greater value, while the presence of a body of distinguished scientific visitors in India cannot fail to be a source of inspiration to students and scientific investigators in that country. 